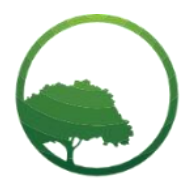

Research in Business \& Social Science

IJRBS VOL 10 NO 8 ISSN: 2147-4478

\title{
Examining the role of organizational climate on career adaptability and government employees' career intention
}

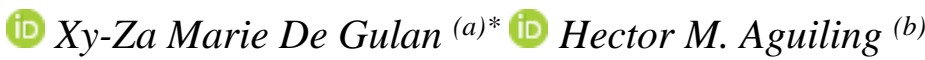 \\ (a) The Graduate School, University of Santo Tomas, Philippines \\ (b) Professor, The Graduate School, University of Santo Tomas, Philippines
}

\author{
ARTICLE INFO \\ Article history: \\ Received 04 December 2021 \\ Received in rev. form 24 Dec. 2021 \\ Accepted 27 December 2021 \\ Keywords: \\ Career intentions, career adaptability, \\ organizational climate, mediating role, \\ moderating role. \\ JEL Classification: \\ M12, M14, M51, M53
}

\begin{abstract}
A B S T R A C T
The purpose of this study is to determine the mediating and moderating factor of organizational climate on the relationship of career adaptability and career intention. A total of 991 employees from a government institution participated in the study. The results showed that there are significant relationships between organizational climate, career adaptability, and career intention. The organizational climate was found to mediate the relationship between career adaptability and career intention. However, the organizational climate has no moderating effect on career adaptability and career intention. The result will be useful in providing guidance in the design and development of programs that will strengthen the employees' career intention and the overall perception of the organizational climate.
\end{abstract}

(C) 2021 by the authors. Licensee SSBFNET, Istanbul, Turkey. This article is an open access article distributed under the terms and conditions of the Creative Commons Attribution (CC BY) license (http://creativecommons.org/licenses/by/4.0/).

\section{Introduction}

Cultivating an organizational climate plays an important role for institutions to become adaptive to uncertainties and rapidly changing work environment caused by economic, political, and cultural changes. New conditions and trends push organizations to explore and capitalize on their human resource to develop and maintain competitive advantage (Wright et al., 2018). They identify various HR interventions to manage and help employees cope and respond to work as they are the ones greatly affected by the unpredictability of work context, career roles, and job expectations (Savickas, 2005; Simosi et al., 2015). Given these circumstances, focusing on managing employee behavior is needed as it may cause organizational ineffectiveness and disruption.

Trevor-Roberts (2006) pointed out that the role of career development is often overlooked whenever there are changes in the work environment. The Career Development in a Pandemic Survey of Doodle (2020) reported that forty-one percent (41\%) of the respondents indicated that their career development was stalled while nine percent (9\%) believed that their careers have regressed. Data on underemployment and unemployment during the pandemic are considered career uncertainties and disruptions as 6.5 million employees were reported underemployed while 3.9 million people remain unemployed as of June 2021 as reported by the Philippine Statistics Authority. The current situation of workers poses challenges on the human resource management on how to mitigate impact of changing work conditions particularly its human resource as they are susceptible to career shift and disruption due to lack of knowledge, opportunities, and resources to support basic needs. Unfortunately, the models, methods, and theories on career development have not kept pace with the new work conditions, which should have guided the organizations today (Wright et al.,

\footnotetext{
* Corresponding author. ORCID ID: 0000-0003-2412-1598

(C) 2021 by the authors. Hosting by SSBFNET. Peer review under responsibility of Center for Strategic Studies in Business and Finance.

https://doi.org/10.20525/ijrbs.v10i8.1521
}

Citation: De Gulan, X.-Z. M., \& Aguiling, H. (2021).Examining the role of organizational climate on career adaptability and government employees' career intention. International Journal of Research in Business and Social Science (2147- 4478), 10(8) 
2018). A study conducted by ATENEO CORD (n.d.) on career development practices shows that organizations with systems on career development that are in existence for around 6 years were rated by respondents with only "somewhat effective" citing that there should be a clear objective of what the system supposed to achieve.

Meanwhile, career employees in the government are among the affected sector in the Philippine labor force which is estimated at 1.5 million Filipinos (Civil Service Commission, 2020). To be able to join the career workers in the government, rigorous requirements must be complied. However, even before the pandemic, selection and promotion system in the government agencies has been taunted with challenges on politics and bureaucracy (Brillantes and Fernandez, 2011), which affect the employees' performance and career expectation. One viable career strategy suggested by Bozeman \& Ponomariov (2009) is that government employees tend to stay in agency and increase their level of responsibility because they assume it will lead to future promotion.

In light of these issues and concerns, the study posits that when the organization cultivates an environment for growth and development, employees will develop high level of career adaptability that will keep them engaged and motivated to accept bigger responsibilities and aim for higher career in the organization. In addition, the study also believes that utilizing organizational level data such as organizational climate to align HR programs in the over-all organization's objective will be a more strategic approach on career development.

\section{Literature Review}

\section{Theoretical and Conceptual Background}

\section{Career Intention}

Career intention is defined as the individual's desire to aim higher career in the organization (Li \& Huang, 2017). It is driven by individual's personal values, psychological needs, perceived career success, and work environment (Mayrhofer et al., 2016; Kessler et al., 2019; Chan et al., 2013; Mignonac \& Herrbach, 2003).

Common barriers of career intention cited in the literature across the years of research remain to be deeply rooted on gender stereotyping, sex discrimination, and political issues (Sadolikar, 2019). Hence, researchers often emphasize the role of organizations in motivating and boosting employees' career intention (Halcomb et al., 2018; Watt \& Richardson, 2008; Kossek et al., 2020). They pointed out that that the organizational structure should promote hierarchal advancement and harness organizational climate where there is an equal support with no distinction on gender (Sanchez \& Lehnert, 2018). Consequently, the employees demonstrating high level of career intention benefit the organizations by contributing to the positive organizational outcomes (Baroudi, 2018; Li \& Huang, 2017; Kwan, 2011).

\section{Career Adaptability}

Career adaptability was introduced by Savickas (1997) as a proposed central construct to replace career maturity in Donald Super's life-space theory on career development. He defined it as an ability and readiness of a person to adjust and respond to unpredictable changes in the work transitions and working conditions. The career abilities have four subscales namely concern, control, curiosity and confidence. These subscales were evaluated to improve and provide relevant insights to introduce various career models to address changes on work conditions, developmental tasks, and career transitions (Porfeli \& Savickas, 2012).

Researchers have taken interest on exploring the relationship and predictive capacity of career adaptability on various constructs focusing on intrinsic (e.g. personal values and traits) and extrinsic (e.g. work environment and conditions) factors (Chen et al., 2020). Career adaptability was found to have significant relationship on intrinsic factors such as perfectionism (Wang et al, 2020), job insecurity (Urbanaviciute et al, 2020), emotional intelligence (Eryilmaz, 2020), career satisfaction (Coetzee \& Takawira, 2019; Shabeer et al., 2018; Ito \& Brotheridge, 2005; Brown, 2016; Veres \& Szamoskozi, 2018); professional competence (Yang et al., 2015) and motivation (Kim \& Lee, 2015), among others. Meanwhile, other researchers tend to focus on the environmental factors as they believe that the formation of one's career is highly influenced by its environment. Factors that were found to be significantly related to career adaptability are social/organizational support (Hou et al., 2019; Takawira, 2020; Yang et al., 2015), organizational career management conditions (Coetzee \& Takawira, 2019), employee engagement (Tladinyane \& Merwe, 2016), and management style (Rezapour \& Ardabili, 2017; Xu \& Yu, 2019).

Although many studies have established the advantages of having high level of career adaptability, there are also results that show negative implications of this construct that organizations should also be mindful of. According to Hsu \& Chang (2019), the result of their study implies that career adaptability moderates the indirect effect of proactive personality and employee turnover. This phenomenon may be explained by the result of Yang's (2015) study that reported that employees who constantly seek new career opportunities (high level of career adaptability) find their current tasks boring.

\section{Organizational climate}

Organizational climate was often interchanged with organizational culture. Hellriegel \& Slocum (1974) and Denison (1996) thoroughly discussed using available literatures the differences and similarities of both concepts in terms of definition, limitations, methodology and its theoretical foundations. Organizational climate was defined in the early literature as a subjective interpretation 
of the organizational characteristics and conditions. Distinctively, this construct under the discipline of psychology uses surface-level manifestations as data to employ comparative analysis to examine organizational behavior and characteristics. Through qualitative methods, climate researchers focused their studies on the perceptual measure of the effectiveness of individual and organizational practices, procedures and initiatives on the dimensions such as organizational structure, responsibility, rewards and recognition, risk management, warmth, organizational support, standards, conflict management, employee identity, among others.

More recent empirical research has begun to shift its perspective on the intervening role of organizational climate between the relationship of two constructs. Punwatkar and Verghese (2018) found out that when the respondents perceived favorable organizational climate, the relationship of competencies and job performance is stronger and significant. Likewise, Addai et al. (2019) were able to establish through hierarchical regression analyses that the relationship of employees working in micro financial institutions tends to show high productive work attitudes under ethical leadership when there is high level of organizational climate. However, when it comes to the topic on career development, it was observed that no study has been conducted yet on the significant relationship and how it moderates the career development constructs such as career adaptability and career intention.

\section{Conceptual Framework}

Figure 1 illustrates the proposed framework. It shows the interaction of employees' demographic profile, career adaptability, organizational climate, and career intention in crafting the career development programs.

The framework aims to prove that employees' level of career adaptability, organizational climate and career intention are influenced by their demographic profile. Meanwhile, the core is focused on the role of organizational climate as mediator and moderator of the relationship between career adaptability and career intention. Karazsia \& Berlin (2018) were able to establish based on their review of literature that a construct may become a mediator and moderator of the same construct. The mediating role occurs when the increase on the level of career adaptability leads to an increase on perceived organizational climate which then increases the level of career intention compared to a direct interaction between career adaptability and career intention. The moderating role, on the other hand, occurs when the change on the level of organizational climate affects the strength of interaction between career adaptability and career intention.

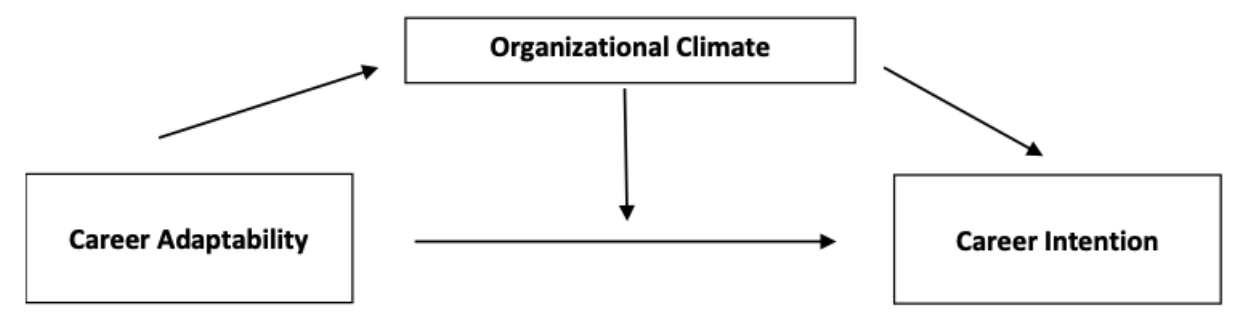

Figure 1: Conceptual Framework

\section{Research and Methodology}

\section{Research Design}

To establish the relationship of the organizational climate, career adaptability and career intention, the quantitative research design was employed.

\section{Participants}

The participants are from a government agency with regional offices and branches from different Philippine regions occupying nonsupervisory positions. Using the purposive sampling technique, employees were selected based on employment status (permanent) and job level criteria (1-6).

Half of the target participants are female (53.28\% or 528) and are between the age of 31-40 years old (48.44\% or 480). The least number of participants are ages 61-64, which are near retirement age of 65, at 16 (1.61\%). In terms of participants' current job level positions, majority of the participants are holding senior positions (job levels 5-6) at 533 or 53.78\%. Participants with less than 10 years of service constitutes to $50.55 \%$ or 501 . Those with $20-29$ and 30 above years of service share almost similar number of respondents at $74(7.47 \%)$ and $76(7.67 \%)$, respectively. Most of the participants are working in the Head Office (597 or $60.24 \%)$. While the other participants are employees in the Plant Complex (196 or 19.78\%) and Regional Offices/Branches in Luzon (95 or 9.59\%), Mindanao (63 or $6.36 \%$ ) and Visayas (40 or $4.04 \%$ ).

\section{Measure}

The instruments used are five-point Likert-type scales to measure the level of participant's agreement on the items relevant to determine their perceived organizational climate, career intention, and career adaptability. 


\section{Climate and Employee Satisfaction Survey}

The Climate and Employee Satisfaction Survey (CESS) is a biennial assessment of the target organization which was designed to assess the employee's job satisfaction and their perception of organizational climate. This study only utilized the Part 1 of the CESS focusing on the nine (9) facets of organizational climate aligned with the organization's 2018-2023 Strategic Map. The instrument consisted of 33 items was intended to measure the 9 facets of organizational climate: Engagement, Work-life Integration, Rewards and Recognition, Structure, Communication, Management Style, Performance Management, Diversity and Inclusion, and Teamwork. According to Byrne (1998), providing three items per scale will contribute in the psychometric property of the instrument (as cited in Maggiori et al., 2015). Hence, the "The working hours required to accomplish my task does not hinder my personal tasks" item for work-life integration facet was added to make each domain have at least three indicators.

Since the psychometric properties of the questionnaire has not yet been established because the organization is using it only for their internal reports, the adapted version of the instrument was subjected to validity and reliability testing. The instrument has been validated by subject matter experts to determine whether the items of the questionnaire measure the constructs that it intends to measure. Four experts from private and government institutions who have vast knowledge on human resource management and human behavior and were asked to evaluate the relevance of the items of the constructs being measured using the five point Likerttype scale ( $1=$ Not relevant/ Not a strength; $5=$ Highly relevant/ Greatest strength) to establish the content validity of the questionnaire. All the dimensions of the organizational climate questionnaire were evaluated with an average score ranging from $4.67-5.00$ with a lowest score of 4 on the item "If so required, I take on additional assignments, or extend work hours to accomplish my tasks" under engagement dimension. The items were considered valid since all experts evaluated the items with above average rating or a score greater than three (Datta \& Singh, 2018).

The instrument was also subjected to pilot testing $(\mathrm{n}=31)$ and was able to demonstrate a Cronbach's alpha coefficient reliability ranging from $0.73-0.87$ for each dimension. The final version of the instrument has a total of 34 items.

Career Adapt-Abilities Scale - Short Form

The Career Adapt-Abilities Scale (CAAS) - Short Form is an abridge version of the widely used CASS International by Porfeli \& Savickas (2012) which measures the four adaptability resources: concern, control, curiosity, and confidence. The CAAS International was validated by Tolentino et al. (2013) to confirm the utility of CAAS in the Philippine context. The short form of the scale, which consists of 12 items, was developed by Maggiori, Rossier \& Savickas (2015) to allow easy integration of the survey to other battery of tests to reduce time spent on accomplishing the tool which is recommended in an organizational setting.

The short form was found to be strongly associated with CAAS International, with an overall Cronbach's coefficient alpha reliability (working samples) of 0.97 (Maggiori et al., 2015). Likewise, the short form was validated and showed good overall Cronbach alpha coefficient for the entire scale ranging from 0.91 to 0.94 (Yu et al., 2019). While the psychometric properties of the instrument were already established, a pilot test $(n=31)$ was conducted to determine the compatibleness of the instrument to target population. The result yielded a Cronbach's alpha coefficient reliability of 0.89 , which is supported by the results of other studies conducted (Eryilmaz et al., 2020; Yang et al., 2015; Urbanaviciute et al., 2020).

\section{Career Intention Questionnaire}

The tool on career intention developed by De Gulan \& Aguiling (2021) aims to measure the government employees' interest to accept new assignments and pursue higher positions in the organization. Items include questions on employees' readiness and willingness to strengthen their skills for career advancements. The tool has 6 items and an overall Cronbach alpha coefficient of 0.82 .

\section{Procedure}

Since the study involves human subjects, the approval of an Ethics Committee was sought. This ensures that the methodology and handling of data follows the guidelines of conducting ethical research. Also, approval from the Head of the organization was requested prior to the conduct of the study. Consultation with concerned Departments was conducted to ensure that protocols on the proper handling of data were taken into consideration. Permission to use the instruments have also been requested from the author/data owner.

The questionnaires and the participant's Information and Informed Consent were deployed to target participants through email to follow the pandemic protocols. Access to answer the questionnaire was limited to 1 week. The email and consent form includes statement that participation is voluntary, expected duration of testing is 10-15 minutes, no discrimination and/or bias among rank and file, and non-participation will not result in any negative effects to their employment status.

\section{Statistical Analysis}

The research findings were presented in tables, graphs, and figures. Descriptive statistics such as frequency, mean, standard deviation, percentage, ANOVA, and Cronbach alpha coefficient were analyzed through the SPSS software. 
To analyze the data and test the hypothesized relationships in the study, Confirmatory Factor Analysis (CFA) and SEM were utilized using the WarpPLS software.

\section{Results and Discussions}

Measurement Test. To estimate the structural model, it is important that fit and quality indices conditions must be within the acceptable limits. Table 1 presents the result of the confirmatory analysis on organizational climate, career adaptability and career intention.

Construct reliability serves as good indicator to measure whether the items are consistent with its intended measure (Streiner, 2003). The construct reliability is acceptable when the Cronbach's alpha reliability coefficient and composite reliability are greater than or equal to 0.70 (Tavakol \& Dennick, 2011). Cronbach's alpha reliability and composite reliability are both measures of internal consistency of items. The Cronbach's alpha reliability coefficient and composite reliability of organizational climate $(\alpha=0.92, \mathrm{CR}=$ $0.93)$, career adaptability $(\alpha=0.84, \mathrm{CR}=0.89)$, and career intentions $(\alpha=0.86, \mathrm{CR}=0.93)$ are all within the acceptable values. This indicates that the instruments have good reliability based on the target samples.

Table 1: Measurement test using confirmatory analysis on organizational climate (OC), career adaptability (CA) and career intention $(\mathrm{CI})$

\begin{tabular}{|c|c|c|c|c|c|c|c|c|c|c|c|c|}
\hline & & $\mathbf{M}$ & SD & $\begin{array}{l}\text { Factor } \\
\text { (range) }\end{array}$ & Loadings & $\alpha$ & CR & AVE & $\mathrm{AVE}^{2}$ & 1 & 2 & 3 \\
\hline 1 & OC & 4.11 & 0.50 & $0.61-0.85 * * *$ & & 0.92 & 0.93 & 0.61 & 0.78 & - & & \\
\hline 2 & $\mathrm{CA}$ & 4.06 & 0.50 & $0.77-0.86^{* * *}$ & & 0.84 & 0.89 & 0.68 & 0.82 & $0.30 * * *$ & - & \\
\hline 3 & CI & 3.85 & 0.72 & $0.72-0.83 * * *$ & & 0.86 & 0.93 & 0.59 & 0.77 & $0.30 * * *$ & $0.52 * * *$ & - \\
\hline
\end{tabular}

Note: $\mathrm{M}=$ mean; $\mathrm{SD}=$ standard deviation; $\alpha=$ Cronbach's alpha; $\mathrm{CR}=$ composite reliability; $\mathrm{AVE}=$ average variance extracted; $\mathrm{AVE}^{2}=$ AVE squared. $N=991$. $* * * p \leq 0.001$.

Convergent validity, which measures the level of respondents' understanding of items is in agreement with how the instrument was developed. It may be assessed using the factor loadings of the indicators of the variables, composite reliability, and the average variance extracted, with an acceptable value of at least $0.60,0.70$, and 0.50 , respectively (Amora et al., 2016). Item loading refers to the correlation between the variable and items. Average variance extracted is the overall distribution attributed to the construct against that of observational error (Ab Hamid et al., 2017). The values in Table 6 show that the acceptable values to establish the convergent validity are all within the acceptable limits. The factor loadings of the indicators of organizational climate $(0.61-0.85)$, career adaptability $(0.77-0.86)$, and career intentions $(0.72-0.83)$ are all greater than 0.60 and are all significant at $p \leq 0.001$. The average variance extracted of organizational climate $(0.61)$, career adaptability $(0.68)$, and career intentions $(0.59)$ are all greater than 0.50 . Hence, the convergent validity of all variables is sufficient.

Table 2: Model fit indices used for the structural model

\begin{tabular}{|l|c|c|c|c|c|c|c|c|c|c|}
\hline & Model 1 & Model 2 & Model 3 & Model 4 & Model 5 & Model 6 & Model 7 & Model 8 & Model 9 & Model 10 \\
\hline APC & $0.270^{* * *}$ & $0.257 * * *$ & $0.224 * * *$ & $0.235^{* * *}$ & $0.233^{* * *}$ & $0.196^{* * *}$ & $0.217^{* * *}$ & $0.200^{* * *}$ & $0.224 * * *$ & $0.245^{* * *}$ \\
\hline ARS & $0.234 * * *$ & $0.230^{* * *}$ & $0.188^{* * *}$ & $0.199^{* * *}$ & $0.204^{* * *}$ & $0.158^{* * *}$ & $0.180^{* * *}$ & $0.168^{* * *}$ & $0.185^{* * *}$ & $0.214 * * *$ \\
\hline AARS & $0.232^{* * *}$ & $0.228^{* * *}$ & $0.187^{* * *}$ & $0.198^{* * *}$ & $0.202^{* * *}$ & $0.157^{* * *}$ & $0.179^{* * *}$ & $0.166^{* * *}$ & $0.184^{* * *}$ & $0.212^{* * *}$ \\
\hline AVIF & 1.176 & 1.153 & 1.078 & 1.094 & 1.136 & 1.039 & 1.106 & 1.097 & 1.095 & 1.115 \\
\hline AFVIF & 1.341 & 1.264 & 1.220 & 1.236 & 1.237 & 1.201 & 1.229 & 1.217 & 1.233 & 1.249 \\
\hline RSCR & 0.983 & 1.000 & 1.000 & 0.995 & 1.000 & 0.984 & 0.994 & 0.993 & 0.991 & 0.999 \\
\hline SSR & 1.000 & 1.000 & 1.000 & 1.000 & 1.000 & 1.000 & 1.000 & 1.000 & 1.000 & 1.000 \\
\hline
\end{tabular}

Note: APC: Average path coefficient; ARS = Average R-squared; AARS= Average Adjusted R-Squared; AVIF= Average block variance inflation factor $(\mathrm{VIF}) ; \mathrm{AFVIF}=$ Average Full collinearity VIF; RSCR= R-squared contribution ratio; SSR= Statistical suppression ration

It is important that discriminant validity is established because it determines whether the items in the instruments cause confusion to participants associating the items of a construct with items of another variable (Kock, 2015). To measure the discriminant validity, the square root of the average variance extracted (AVE2) is greater than the correlation coefficient when it is correlated with the other variables. AVE2 results show acceptable discriminant validity for organizational climate (0.78), career adaptability $(0.82)$ and career intention (0.77).

Tests of construct validity, convergent validity, and discriminant validity are found to be sufficient on the conditions to estimate the structural model for the mediating and moderating role of organizational climate and its dimensions on career adaptability and career intention. As shown in Table 2, the model fit indices used to assess the structural model fits with the data very well.

Mediating role of organizational climate. The structural model test result in Table 3 supports the hypothesis which indicates that organizational climate mediates the relationship of career adaptability and career intentions $(\beta=0.05, p \leq 0.05)$. The extent of the 
effect of OC is small $\left(f^{2}=0.03\right)$. Among the organizational climate dimensions, only engagement $(\beta=0.08, p \leq 0.001)$ and work-life integration $(\beta=0.07, p \leq 0.01)$ with small effect size $\left(f^{2}=0.04\right)$. The small effect size is considered acceptable for studies on social sciences as the aim is to only establish causal relationship among constructs (Moksony, 1999).

The result implies that organizational climate, particularly the engagement and work-life integration dimensions, strengthens the relationship of the career adaptability and career intention when it acts as mediator between the two variables. Mediation occurs when the career adaptability leads to a change on how employees perceive the organizational climate, which then will lead to a change on employees' career intention. Various studies were able to test the mediating effect of organizational climate but only few tested its mediating effect on employees' career intention. The result on its dimensions were comparable to research literature on mediating effect of engagement (Tasdelen-Karckay \& Bakalim, 2017; Amin, 2013; Umamaheswari \& Krishnan, 2016) and worklife integration (Al-Tit \& Hunitie, 2015; Alias et al., 2014).

Moderating role of organizational climate. The result on Table 4 indicates that the relationship of career adaptability and career intention is not moderated by organizational climate $(\beta=-0.01)$ with effect size that is insignificant $(\mathrm{f} 2=0.00)$.

The test of moderating effect aims to check the influence of perceived level of organizational climate and its dimensions on the strength of the relationship between career adaptability and career intention. Of the limited available literature, some are noted to find a different result on their attempt to determine the moderating role of organizational climate on the employees' career outcomes behavior. Vahedi (2020) was able to find evidence that organizational climate moderates the relationship of spiritual intelligence and stagnation on the career advancement of employees. Elmas-Atay (2017) also reported the significant effect of engagement on work values and subjective career success. Lastly, Santhanam et al. (2020) noted the significant effect of work-life balance in the relationship between selected HRM practices (training, career growth opportunity, and turn over intention).

Table 3: Mediating effect of organizational climate (OC) on career adaptability (CA) and career intention (CI)

\begin{tabular}{lllll}
\hline Path & Mediator & Direct & $\boldsymbol{\beta}$ & $\mathbf{f}^{2}$ \\
\hline CA to CI & $----\cdots----$ & 0.55 & & \\
\hline & Overall OC & 0.50 & $.049 *$ & 0.03 \\
\hline
\end{tabular}

Note: $\beta=$ path coefficient. $\mathbf{f}^{2}=$ Cohen's effect size: $.02=$ small, $.15=$ moderate, $.35=$ large

$N=991 . * p \leq 0.05 ; * * p \leq 0.01 ; * * * p \leq 0.001$.

Table 4: Moderating effect of organizational climate (OC) on career adaptability (CA) and career intention (CI)

\begin{tabular}{lcccc}
\hline Path & Moderator & Direct & $\boldsymbol{\beta}$ & $\mathbf{f}^{2}$ \\
\hline CA to CI & ---------- & 0.55 & & 0.00 \\
\hline & Overall OC & 0.50 & -0.01 & \\
\hline
\end{tabular}

Note: $\beta=$ path coefficient. $\mathbf{f}^{2}=$ Cohen's effect size: $.02=$ small, $.15=$ moderate, $.35=$ large

$N=991 . * p \leq 0.05 ; * * p \leq 0.01 ; * * * p \leq 0.001$.

\section{Conclusion}

The purpose of the study is to recognize the importance of organizational level data such as organizational climate in designing career development programs of employees, particularly those that are working in the government. Interestingly, while the organizational climate does not moderate the relationship of career adaptability and career intention, it was found to mediate its relationship. These findings provide relevant insights on how human resource management data may be utilized to align human resource with the organizations' over-all objectives. It is also essential, especially today as working environment becomes more dynamic, that the employees are driven and with good sense of career direction.

While the validity and reliability were established, several limitations have been noted. First, respondents of this study only covered rank and file government employees with permanent positions. This did not cover employees who are contractual and co-terminus. Also, due to data privacy concerns, the demographic profile of respondents did not cover factors such as name of organization and department/office of employees.

Second, constructs on organizational climate and career intention were developed based on the target organizations' definition and programs on career intention and their identified relevant organizational climate dimensions.

Lastly, the focus of the study is on the mediating and moderating factor of organizational climate and its dimensions on career adaptability and career intention. The result of which will be used as inputs in the development of a career development model. The data collected are not intended to evaluate or assess the efficiency and effectiveness of the target organization's organizational climate and career intervention programs. 
Author Contributions: Conceptualization, XMDG., HMA.; Methodology, XMDG., HMA.; Data Collection, XMDG., HMA.; Formal Analysis, XMDG., HMA.; Writing — Original Draft Preparation, XMDG., HMA.; Writing—Review And Editing, XMDG., HMA.; All authors have read and agreed to the published the final version of the manuscript.

Institutional Review Board Statement: Ethical review and approval were waived for this study, due to that the research does not deal with vulnerable groups or sensitive issues.

Data Availability Statement: The data presented in this study are available on request from the corresponding author. The data are not publicly available due to privacy.

Conflicts of Interest: The authors declare no conflict of interest.

\section{References}

Ab Hamid, M., Sami, W., \& Mohmad, S. (2017). Discriminant validity assessment: Use of Fornell and Larcker criterion versus HTMT criterion. Journal of Physics, 890, 012163. https://doi.org/10.1088/1742-6596/890/1/012163

Addai, P., Avor, J., Ofori, I., \& Tweneboah, D. (2019). Ethical leadership and productive work attitudes among micro financial institutions in Ghana: moderating role of organizational climate. Management Research Review, 42(9), 1049-1061. https://doi.org/10.1108/MRR-06-2018-0235

Al-Tit, A., \& Hunitie, M. (2015). The mediating effect of employee engagement between its antecedents and consequences. Journal of Management Research, 7(5), 47-62. https://doi.org/10.5296/jmr.v7i5.8048

Alias, N., Noor, N., \& Hassan, R. (2014). Examining the mediating effect of employee engagement on the relationship between talent management practices and employee retention in the information and technology (IT) organizations in Malaysia. Journal of Human Resources Management and Labor Studies, 2(2), 227-242. https://doi.org/10.15640/jhrmls

Amin, Z. (2013). The mediating effect of quality of work life on the relationship between career development and psychological well-being. International Journal of Research Studies in Psychology, 2(3). https://doi.org/10.5861/ijrsp.2013.259

Amora, J. (2021). Convergent validity assessment in PLS-SEM: A loadings-driven approach. Data Analysis Perspectives Journal, 2(3), 1-6.

Baroudi, S.E., Khapova, S.N., Fleisher, C., \& Jansen P.G.W. (2018). How do career aspirations benefit organizations? The mediating roles of the proactive and relational aspects of contemporary work. Frontiers in Psychology, 9(2150), 1-11. https://doi.org/10.3389/fpsyg.2018.02150

Brown, A. (2016). Career adaptability and attitudes to low-skilled work by individuals with few qualifications: 'getting by', 'getting on' or 'going nowhere'. British Journal of Guidance \& Counseling, 44(2), 221-232. http://dx.doi.org/10.1080/03069885.2016.1145196

Byrne, B. M. (1998). Structural equation modeling with LISREL, PRELIS, and SIMPLIS: Basic concepts, applications, and programming. In Maggiori, C., Rossier, J. \& Savickas, M. (2015). Career Adapt-Abilities Scale-Short Form (CAAS-SF): Construction and Validation. Journal of Career Assessment, 1-14. https://doi.org/10.1177/1069072714565856

Chan, Z., Tam, W., Lung, M., Wong, W., \& Chau, C. (2013). A systematic literature review of nurse shortage and the intention to leave. Journal of Nursing Management, 21(4), 605-13. https://doi.org/10.1111/j.1365-2834.2012.01437.x

Chen, H., Fang, T., Liu, F., Pang, L., Wen, Y., Chen, S., \& Gu, X. (2020). Career adaptability research: A literature review with scientific knowledge mapping in web of science. Int. J. Environ. Res. Public Health, $17,5986$. https://doi.org/10.3390/ijerph17165986

Coetzee, M., \& Takawira, N. (2019). Career satisfaction of professional women: The interplay between career adaptability and psychosocial career preoccupations. African Journal of Employee Relations, 43(3764), 1-17. https://doi.org/10.25159/2520$3223 / 3764$

Datta, A., \& Singh, R. (2018). Determining the dimensions of organizational climate perceived by the hotel employees. Journal of Hospitality and Tourism Management, 36, 40-48. https://doi.org/10.1016/j.jhtm.2018.07.001

De Gulan, X. \& Aguiling, H. (2021). Measure of Government Employees' Career Intentions: Design and Validation of Questionnaire. European Journal of Education Studies, 8(10), 121-128, https://doi.org/10.46827/ejes.v8i10.3933

Denison, D. (1996). What is the difference between organizational culture and organizational climate? A native's point of view on a decade of paradigm wars. The Academy of Management Review, 21(3), https://doi.org/619-654.0.2008.01942.x

Doodle Blog. (2020, September 17). Career Development in a Pandemic. https://doodle.com/en/resources/

Elmas-Atay, S. (2017). Work values fit and subjective career success: The moderating role of work engagement. International Review of Management and Marketing, 7(3), 113-120.

Eryilmaz, A., Satici B., \& Deniz M.E. (2020). A model of career adaptability for teachers: emotional intelligence, goal setting, and striving for goals. International Online Journal of Primary Education, 9(1), 63-72.

Halcomb, E., Smyth, E., \& McInnes, S. (2018). Job satisfaction and career intentions of registered nurses in primary health care: An integrative review. BMC Family Practice, 19(136), 1-14. https://doi.org/10.1186/s12875-018-0819-1

Hou, C., Wu, Y., \& Liu, Z. (2019). Career decision-making self-efficacy mediates the effect of social support on career adaptability: A longitudinal study. Social Behavior and Personality: An International Journal, 47(5), e8157. https://doi.org/10.2224/sbp.8157

Hsu, C.T., \& Chang, W.Y. (2019). How proactive personality can decrease turnover intention: A moderated mediation model of justice perception and career adaptability in Taiwanese nurses. Corporate Management Review, 39(2), 1-35. 
Ito, J. \& Brotheridge, C. (2001). An Examination of the Roles of Career Uncertainty, Flexibility, and Control in Predicting Emotional Exhaustion, Journal of Vocational Behavior, 59(3), 406-424. https://doi.org/10.1006/jvbe.2001.1800

Kessler, I., Bach, S., \& Nath, V. (2019). The construction of career aspirations amongst healthcare support workers: beyond the rational and the mundane?. Industrial Relations Journal, 50(2), 150-167. https://doi.org/10.1111/irj.12245

Kim, N.R., and Lee, K.H. (2015). The effect of internal locus of control on career adaptability: the mediating role of career decisionmaking self-efficacy and occupational engagement. American Counseling Association, 55, 2-15. https://doi.org/10.1002/joec.12069

Kock, N. (2015). Common method bias in PLS-SEM: A full collinearity assessment approach. International Journal of eCollaboration, 11(4), 1-10. https://doi.org/10.4018/ijec.2015100101

Kossek, E.E., \& Malaterre, A. (2019). Desperately seeking sustainable careers: Redesigning professional jobs for the collaborative crafting of reduced-load work. Journal of Vocational Behavior, 117. https://doi.org/10.1016/j.jvb.2019.06.003

Kwan, P. (2011). Examining the mediating effect of job satisfaction on the relation between responsibilities and career aspiration of vice-principals. International Journal of Educational Research, 50(5-6), 349-361. https://doi.org/10.1016/j.ijer.2011.11.004

Li, Y., and Huang, S. (2017). Hospitality service climate, employee service orientation, career aspiration and performance: A moderated mediation model. International Journal of Hospitality Management, 67, $24-32$. https://doi.org/10.1016/j.ijhm.2017.07.012

Litwin, G., \& Stringer, R. (1996). The influence of organizational climate on human motivation. In Hellriegel, D., \& Slocum, Jr., J. (1974). Organizational climate: Measures, research and contingencies, Academy of Management Journal, 17(2), 255-280. https://doi.org/10.2307/254979

Maggiori, C., Rossier, J. \& Savickas, M. (2015). Career Adapt-Abilities Scale-Short Form (CAAS-SF): Construction and Validation. Journal of Career Assessment, 1-14. https://doi.org/10.1177/1069072714565856

Mayrhofer, W. et al. (2016). (2016). Career success across the globe: Insights from the 5C project. Organizational. Dynamics, 45(2), 1-25. https://doi.org/10.1016/j.orgdyn.2016.07.005

Mignonac, K., \& Herrbach, O. (2003). Managing individual career aspirations and corporate needs: A study of software engineers in France. Journal of Engineering and Technology Management, 20, 205-230. https://doi.org/10.1016/S0923-4748(03)00019-5

Moksony, F. (1999). Small is beautiful. The use and interpretation of R2 in social research. Szociológiai Szemle, 130-138.

Porfeli, E., \& Savickas M. (2012). Career Adapt-Abilities Scale-USA form: Psychometric properties and relation to vocational identity. Journal of Vocational Behavior, 80(3), 748-753. https://doi.org/10.1016/j.jvb.2012.01.009

Punwatkar, S., \& Verghese, M. (2018). The moderating role of organizational climate in competency-performance relationship: A study on salespersons in Central India. The IUP Journal of Organizational Behavior, 17(4), 36-57.

Rezapour, F., \& Ardabili, F. (2017). Leader-member exchange and its relationship with career adaptability and job satisfaction among employees in public sector. International Journal of Organizational Leadership, 6(3), 425-433. https://doi.org/10.33844/ijol.2017.60405

Sadolikar, U. (2019). Global scenario of women's career aspirations: A literature review. Journal of Psychosocial Research, 14(2), 403-410. https://doi.org/10.32381/JPR.2019.14.02.18

Sanchez, C., \& Lehnert, K. (2018). The unbearable heaviness of leadership: The effects of competency, negatives, and experience on women's aspirations to leadership. Journal of Business Research, 95, 182-194. https://doi.org/10.1016/j.jbusres.2018.10.033

Santhanam, N., Kumar, J., Kumar, V., \& Saha, R. (2020). Employee turnover intention in the milieu of human resource management practices: Moderating role of work-life balance. International Journal of Business Innovation and Research. 24(1). https://doi.org/10.1504/IJBIR.2021.111979

Savickas, M. (1997). Career adaptability: An integrative construct for Life- Span, Life- Space Theory. The Career Development Quarterly, 45, 247-259. https://doi.org/10.1002/j.2161-0045.1997.tb00469.x

Savickas, M. L. (2005). The theory and practice of career construction. In Chen, H., Fang, T., Liu, F., Pang, L., Wen, Y., Chen, S., $\& \mathrm{Gu}, \mathrm{X}$. (2020). Career adaptability research: A literature review with scientific knowledge mapping in web of science. International Journal of Environmental Research and Public Health, 17, 5986. https://doi.org/10.3390/ijerph17165986

Shabeer, S., Mohammed., S., Jawahar, I.M., \& Bilal, A.R. (2019). The mediating influence of fit perceptions in the relationship between career adaptability and job content and hierarchical plateaus. Journal of Career Development, 46(3) 332-345. https://doi.org/10.1177/0894845318763960

Simosi, M., Rousseau, D., \& Daskalaki, M. (2015). When career paths cease to exist: A qualitative study of career behavior in a crisis economy. Journal of Vocational Behavior, 91, 134-146. https://doi.org/10.1016/j.jvb.2015.09.009

Takawira, N. (2020). Mediation effect of perceived organisational and social support in the relationship between career adaptability and career satisfaction among professional women. Journal of Psychology in Africa, 30(1), 23-29. https://doi.org/10.1080/14330237.2020.1716550

Tasdelen-Karckay, A. \& Bakalim, O. (2017). The mediating effect of work-life balance on the relationship between work-family conflict and life satisfaction. Australian Journal of Career Development, 26(1), 3-13. https://doi.org/10.1177/1038416216682954

Tavakol, M. \& Dennick, R. (2011). Making sense of Cronbach's alpha. International Journal of Medical Education. 2, $53-55$. https://doi.org/10.5116/ijme.4dfb.8dfd 
Tolentino, L., Garcia, P.R.J., Restubog, S.L., Bordia, P., and Tang, R. (2013). Validation of the Career Adapt-Abilities Scale and an examination of a model of career adaptation in the Philippine context. Journal of Vocational Behavior, 83(3), 410-418. doi.org/10.1016/j.jvb.2013.06.013

Trevor-Roberts, E. (2006). Are you sure? The role of uncertainty in career. Journal of Employment Counseling, 43(3). https://doi.org/10.1002/j.2161-1920.2006.tb00010.x

Trevor-Roberts, E., Parker, P. \& Sandberg, J. (2018). How uncertainty affects career behaviour: A narrative approach. Australian Journal of Management, 44(1), 50-69. https://doi.org/10.1177/0312896218775801

Umamaheswari, S., \& Krishnan, J. (2016). Retention of employees in ceramic sanitary ware factories in India: Role of work life balance, career development and supervisor support. TEM Journal, 5(2). https://doi.org/10.18421/TEM52-15

Urbanaviciute, I., Udayar, S., Maggiori1, C., and Rossier, J. (2020). Precariousness profile and career adaptability as determinants of job insecurity: A three-wave study. Journal of Career Development, 47(2) 146-161. https://doi.org/10.1177/0894845318791777

Vahedi, M. (2020). Investigating the effect of spiritual intelligence on stagnation in the career development of human capital with the moderating role of organizational climate in Payame Noor University of East Azerbaijan Province. Public Organizations Management, 9(1), https://doi.org/10.30473/ipom.2020.54638.4174

Veres, A., \& Szamosközi, I. (2018). Career stage as a moderator of the relationship between career adaptability and professional well-being: A meta- analysis. Transylvanian Journal of Psychology, 19(2), 82-108.

Watt, H., \& Richardson, P. (2008). Motivations, perceptions, and aspirations concerning teaching as a career for different types of beginning teachers. Learning and Instruction, 18, 408-428. https://doi.org/ 10.1016/j.learninstruc.2008.06.002

Wright, P., Nyberg, A., \& Ployhart, R. (2018). A research revolution in SHRM: New challenges and new research directions. Research in Personnel and Human Resources Management, 36, 141-163. https://doi.org/10.1108/S0742730120180000036004

Xu, X. \& Yu, K., (2018). When core self-evaluation leads to career adaptability: Effects of ethical leadership and implications for citizenship behavior. The Journal of Psychology, 153(5), 463-477. https://doi.org/10.1080/00223980.2018.1564724

Yang, W., Guan, Y., Lai, X., She, Z., \& Lockwood, A.J. (2015). Career adaptability and perceived overqualification: Testing a dualpath model among Chinese human resource management professionals. Journal of Vocational Behavior, 154-162. https://doi.org/10.1016/j.jvb.2015.08.007

Yu, H., Dai, Y., Guan, X. \& Wang, W. (2019). Career Adapt-Abilities Scale-Short Form (CAAS-SF): Validation Across Three Different Samples in the Chinese Context. Journal of Career Assessment, 20(10), 1-20. https://doi.org/10.1177/1069072719850575

Publisher's Note: SSBFNET stays neutral with regard to jurisdictional claims in published maps and institutional affiliations.

\section{(a) (1)}

(C) 2021 by the authors. Licensee SSBFNET, Istanbul, Turkey. This article is an open access article distributed under the terms and conditions of the Creative Commons Attribution (CC BY) license (http://creativecommons.org/licenses/by/4.0/).

International Journal of Research in Business and Social Science (2147-4478) by SSBFNET is licensed under a Creative Commons Attribution 4.0 International License. 